\title{
Addressing key limitations associated with modelling soil erosion under the impacts of future climate change
}

\author{
Donal Mullan $^{\mathrm{a}, *}$, Dave Favis-Mortlock ${ }^{\mathrm{b}}$, Rowan Fealy ${ }^{\mathrm{c}}$ \\ a School of Geography, Archaeology and Palaeoecology, Queen's University Belfast, Belfast, BT7 1NN County Antrim, Northern Ireland, UK \\ ${ }^{\mathrm{b}}$ Environmental Change Institute, School of Geography and the Environment, University of Oxford, South Parks Road, Oxford OX1 3QY, UK \\ ' School of Geography, National University of Ireland Maynooth, Maynooth, County Kildare, Republic of Ireland
}

\section{A R T I C L E I N F O}

\section{Article history:}

Received 23 April 2011

Received in revised form 24 October 2011

Accepted 21 December 2011

\section{Keywords:}

Soil erosion

Climate change

Statistical downscaling

Land use and management

Sub-daily rainfall intensity

Northern Ireland

\begin{abstract}
A B S T R A C T
Future climate change is expected to impact the extent, frequency, and magnitude of soil erosion in a variety of ways. The most direct of these impacts refers to the projected increase in the erosive power of rainfall, whilst other more indirect impacts include changes in plant biomass and shifts in land use to accommodate the new climatic regime. Given the potential for climate change to increase soil erosion and its associated adverse impacts, modelling future rates of erosion is a crucial step in its assessment as a potential future environmental problem, and as a basis to help advise future conservation strategies. Despite the wide range of previous modelling studies, in the majority of cases limitations are apparent with respect to their treatment of the direct impacts (changed climate data), and their failure to factor in the indirect impacts (changing land use and management). In this study, these limitations are addressed in association with the modelling of future soil erosion rates for a case study hillslope in Northern Ireland using the Water Erosion Prediction Project (WEPP) model. The direct impacts are handled using statistical downscaling methods, enabling the generation of site-specific, daily resolution future climate change scenarios, and a simple sensitivity analysis approach is employed to investigate the previously unstudied impacts of sub-daily rainfall intensity changes. Finally, the frequently neglected indirect impacts are examined using a scenarios-based approach. Results indicate a mix of soil erosion increases and decreases, depending on which scenarios are considered. Downscaled climate change projections in isolation generally result in erosion decreases, whereas large increases are projected when land use is changed from the current cover of grass to a row crop which requires annual tillage, and/or where large changes in subdaily rainfall intensity are applied. The overall findings illustrate the potential for increased soil erosion under future climate change, and illuminate the need to address key limitations in previous studies with respect to the treatment of future climate change projections, and crucially, the factoring in of future land use and management.
\end{abstract}

(C) 2011 Elsevier B.V. All rights reserved.

\section{Introduction}

Soil erosion is a major environmental threat to the sustainability and productive capacity of agriculture (Yang et al., 2003; Feng et al., 2010). It is estimated that around 10 million hectares of cropland are lost to erosion annually (Yang et al., 2003; Pimentel, 2006). With world population projected to increase by $47 \%$ from the start to the mid-point of the 21st century (UN, 2005), global food demand is increasing at a time when per capita food productivity is beginning to decline. This reduction in soil productivity and fertility, which represents the most significant of the 'on-site impacts' of soil erosion, is most prevalent in the tropical and subtropical agroecosystems of Asia, Africa and South America, where

\footnotetext{
* Corresponding author. Tel.: +44 07749147953.

E-mail address: dmullan15@qub.ac.uk (D. Mullan).
}

soil loss averages 30-40 t/ha/year (Taddese, 2001). In temperate regions, meanwhile, it is the 'off-site impacts' of soil erosion that tend to present a greater problem. The term 'muddy flood' perhaps best encapsulates the off-site impacts of erosion, describing the flow of water and sediment out of agricultural fields, resulting in downslope damage to properties, roads and watercourses (Boardman, 2010). Studies from around Europe have estimated the costs of muddy floods, resulting from damage to private householders and public infrastructure, revealing costs of $€ 957,000$ following a single event in Brighton, England in 1987 (Robinson and Blackman, 1990), $€ 118$ ha $^{-1}$ year $^{-1}$ in Soucy, France over a ten year period, and a mean annual cost of around $€ 14-140$ million year $^{-1}$ in Belgium (Evrard et al., 2007). Erosion has also been recognised as a major non-point pollution source that adversely affects ecosystem water quality (Cochrane and Flanagan, 1999). In Ireland, for example, the generally low permeability of soils, coupled with gentle stream courses, mean runoff rates are among the highest in 
Western Europe (Wilcock, 1997). This results in the off-site transport of agricultural pollutants in runoff, with nitrate and phosphate from agricultural fertilisers considerably degrading water quality in major Irish lakes such as Lough Neagh and Lower Lough Erne (e.g. Anderson, 1997; Watson et al., 2000; Watson and Foy, 2001).

The incidence of these adverse impacts of soil erosion may become a more significant problem, since future climate change is expected to impact the extent, frequency, and magnitude of soil erosion in a variety of ways (Pruski and Nearing, 2002a). The most direct of the impacts of climate change on soil erosion is the change in the erosive power of rainfall (Favis-Mortlock and Savabi, 1996; Williams et al., 1996; Favis-Mortlock and Guerra, 1999; Nearing, 2001; Pruski and Nearing, 2002a). Increases in global temperature lead to increases in the moisture-holding capacity of the atmosphere at a rate of about $7 \%$ per $1^{\circ} \mathrm{C}$. This results in increased water vapour in the atmosphere, and ultimately a more vigorous hydrological cycle (Nearing et al., 2005), promoting a trend towards more intense precipitation events (Trenberth et al., 2003). Climate models are projecting a continued increase in intense precipitation events during the 21st century (IPCC, 2007). Another potential consequence of climate change upon soil erosion relates to changes in plant biomass, with complex changes that can both increase erosion rates through faster residue decomposition from increased microbial activity (Nearing et al., 2005), and decrease erosion rates through an increase in soil surface canopy cover and biological ground cover (Rosenzweig and Hillel, 1998). A more indirect potential impact of climate change on soil erosion refers to shifting agricultural practice and hence land use to accommodate the new climatic regime (Williams et al., 1996). Reacting to changes in climate could range from changing planting dates to the implementation of new crops or complete land use changes, which have the potential to significantly alter soil erosion rates and patterns (Nearing et al., 2005). For example, the introduction of new crops suited to warmer conditions, such as maize and sunflowers, increase risk of erosion as both take a significant amount of time to provide adequate crop cover in early summer (Boardman and Favis-Mortlock, 1993).

Given the potential for climate change to increase soil erosion and its associated adverse impacts, modelling future rates of erosion is a crucial step in its assessment as a potential future environmental problem. Prediction models have become increasingly important tools in the assessment of soil erosion and are the only practicable means of assessing the response of soil erosion to future climate change (Lal, 1998; Toy et al., 2002). In particular, the Water Erosion Prediction Project (WEPP) model (Flanagan and Nearing, 1995) has been widely used in the prediction of future erosion rates under climate change (e.g. Favis-Mortlock and Boardman, 1995; Favis-Mortlock and Guerra, 1999, 2000; Pruski and Nearing, 2002a,b; Zhang et al., 2004, 2009; O'Neal et al., 2005; Zhang, 2005, 2007; Zhang and Liu, 2005; Zhang and Nearing, 2005; Klik and Eitzinger, 2010). The WEPP model is a physically-based, continuous simulation model that simulates hydrology, water balance, plant growth, soil, and erosion at field, hillslope, and small watershed scales. In this study, WEPP is used to model soil erosion under the impacts of future climate change for a hillslope in Northern Ireland. In association with this, the case study aims to illuminate some of the key issues associated with modelling soil erosion under future climate change, by reviewing and critiquing the methodologies used in previous studies, and then outlining approaches to address them.

\section{Previous studies and their limitations}

A number of modelling studies have investigated the impact of future climate change on soil erosion (Table 1). Three fundamental

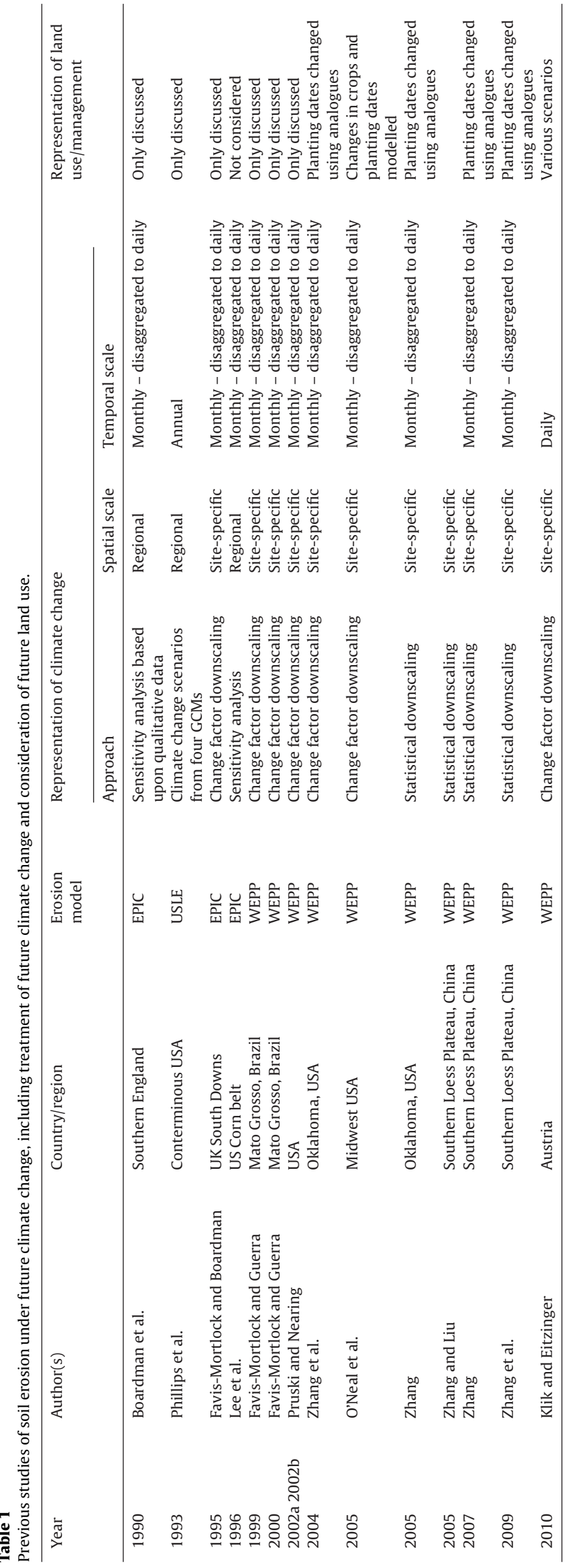


limitations are apparent to varying degrees in the vast majority of these studies. Such limitations refer to: (1) the spatial scale at which climatic changes are represented; (2) the temporal scale at which climatic changes are represented; and (3) the representation of changes in land use and management.

\subsection{The spatial scale of climate data}

General Circulation Models (GCMs) have emerged as the key basis for representing changed climate conditions in studies of future soil erosion since the mid-late 1990s (Favis-Mortlock and Boardman, 1995). GCMs are numerical models representing physical processes in the atmosphere, ocean, cryosphere and land surface. They are currently the most suitable tools for projecting future climate change (IPCC, 2007). Due to the coarse spatial resolution of GCMs and the much finer scale nature of soil erosion, however, methods for generating higher resolution climate change projections are required to more robustly model future erosion rates for individual sites. Downscaling techniques are utilised to bridge the spatial and temporal resolution gap between what is currently provided by GCMs and the requirements of impact assessors (Wilby and Wigley, 1997). Of the various downscaling techniques available, the change factor method is the most commonly used in the modelling of erosion under future climate change (Table 1 ). This method involves perturbing present-day baseline observational data (commonly time series of monthly or daily data) with grid box scale changes inferred from GCM data (Crawford, 2007). The key advantage to the change factor approach is the simplicity and speed of calculation, and direct scaling of projections in line with changes projected by the host GCM (Crawford, 2007). In modifying baseline climate with direct GCM output, however, the change factor method reflects a form of 'implicit downscaling' (Zhang, 2007). This method incorporates climatic characteristics of the target station as well as the areal-averaged relative climate changes projected at the GCM grid level, but fails to consider differences between climate variability at the GCM grid scale and at the target station (Zhang, 2007). Such studies clearly fail to represent realistic conditions of precipitation changes under global climate change, since changes to the number of wet days, precipitation duration and peak intensity of rainfall events are likely to accompany changes in precipitation amount and yet are only partially considered in the implicit method (Pruski and Nearing, 2002a). In addressing the limitations associated with the change factor approach, Zhang (2005) developed a method for statistically downscaling GCM monthly output at grid scale to daily output at local station scale using univariate transfer functions, by calibrating probability distributions of GCMprojected monthly precipitation and temperature to match those of local climatology for the period 1950-1999. These methods were used to model soil erosion under future climate change in Oklahoma, U.S.A. (Zhang, 2005), and in the southern Loess Plateau, China (Zhang and Liu, 2005; Zhang et al., 2009). This method involves firstly spatially downscaling GCM estimates of climate change at the native GCM grid-scale to station-scale climate data using transfer functions, with a subsequent temporal downscaling of monthly values to daily values at the station-scale using the WEPP weather generator CLIGEN (Nicks et al., 1995). Despite these recent advances in downscaling, many studies continue to employ the change factor approach (see Table 1).

\subsection{The temporal scale of climate data}

In addition to the limitations associated with the spatial scale of climate data, almost all of the studies in Table 1 possess limitations with respect to the temporal scale of climate data for input to erosion models. The GCM data applied to observed station data using the change factor approach is most commonly provided at a monthly resolution. In most instances, weather generators are then used to disaggregate monthly data into daily input data required to drive the erosion model (Richardson, 1981; Nicks et al., 1994). For input to process-based models such as WEPP, GCM-guided changes in monthly precipitation presents the problem of how to attribute precipitation change in terms of changes to the number of wet days and amount of precipitation on a wet day (i.e. daily precipitation intensity), since CLIGEN requires both inputs. Many of the studies in Table 1, for example, changed only the amount of precipitation on a wet day, a practice which Pruski and Nearing (2002b) indicate will cause the investigator to overestimate the effects of precipitation change on runoff and erosion. Their recommendation was that a hybrid approach should be employed; attributing half the change to number of wet days and the other half to precipitation amount on wet days. In developing an explicit spatiotemporal downscaling method, Zhang et al. (2004) addressed the issue of attributing precipitation change to precipitation amount and number of wet days by developing linear relationships between transitional probabilities and mean monthly precipitation amount using historical station records and then using linear interpolation to estimate future transitional probabilities for the projected precipitation amount. Despite improvements in the treatment of precipitation changes on a daily basis for input to soil erosion models, there remains the need to provide increased temporal resolution in order to account for the two pathways whereby peak rainfall intensity may be changed in WEPP. The first pathway is controlled by changing daily precipitation amount and variance, whilst changes in sub-daily rainfall intensity represent the second pathway, through changing the average maximum 30 min precipitation intensity parameter (MX.5P) in WEPP(Yu, 2003). Sub-hourly breakpoint rainfall data is required to generate observed values for this parameter. This is easily produced from observed sub-hourly rainfall data, but future output from GCMs is generally deemed unreliable at temporal scales finer than daily (Brissette et al., 2006). With this issue clearly presenting a problem for perturbing the MX.5P parameter to generate future peak rainfall intensity data, to the knowledge of the authors no previous studies have attempted any modifications.

\subsection{Lack of consideration for changes in land use and management}

Despite the multiple ways in which climate change impacts soil erosion, previous modelling studies have generally been restricted to investigating only the direct impacts, i.e. changes in rainfall and temperature, with no consideration given to the potential for increased erosion through changes in land use and management. Some recent emphasis, however, has been placed on factoring changes in land use and management into future erosion modelling. For example, Zhang (2005) used a subjective analogue approach to assessing future management conditions, by utilising planting and harvesting dates from northern Texas to represent future planting and harvesting dates in Oklahoma, on the premise that the present temperature regime in northern Texas was similar to that projected for Oklahoma. O'Neal et al. (2005) utilised a more objective approach, basing future economically viable crops on studies from Pfeifer and Habeck (2002) using the Purdue University Crop/Livestock Linear Programming model (PC/LP) (Dobbins et al., 1994), with future planting dates and expected yields based on crop yield simulations conducted by Southworth et al.(2002) using the Decision Support System for Agrotechnology Transfer (DSSAT) (Hoogenboom et al., 1999). Despite these recent contributions, the vast majority of previous and present studies continue to neglect the need for changes in land use and management. 


\subsection{Addressing key limitations}

This study aims to address the aforementioned methodological shortcomings in association with the modelling of soil erosion under future climate change for a case study hillslope in Northern Ireland. The objectives of the study are to: (1) address the limitations associated with the spatial scale of climate data for input to WEPP by statistically downscaling GCM output to a site-specific spatial scale; (2) address the temporal scale issues by conducting a simple sensitivity analysis approach to developing sub-hourly rainfall intensity changes; (3) address the limitations associated with the indirect impacts of climate change by developing a scenariosbased approach to developing future land use and management changes; and (4) examine the response of soil erosion to the projected future climate and land use changes for a case study hillslope in Northern Ireland using the WEPP model.

\section{Materials and methods}

\subsection{Site description}

The study site, herein referred to as Loughmuck hillslope, is a pasture field located near Omagh, County Tyrone in Northern Ireland (Fig. 1). The hillslope is $180 \mathrm{~m}$ long and approximately $150 \mathrm{~m}$ wide (although delineating hillslope width is subjective and the true width may lie anywhere between $100 \mathrm{~m}$ and $200 \mathrm{~m}$ wide). The slope is of relatively uniform steepness with an average slope angle of $9 \%$ for approximately the upper $150 \mathrm{~m}$, whilst the lower $30 \mathrm{~m}$ levels out into a flat depression as it meets a field boundary. The soil type is a silt loam with $59 \%$ silt content, $3 \%$ organic matter, and a rock content (particle size $>2 \mathrm{~mm}$ ) of $9 \%$. The climate of the area is heavily influenced by its proximity to the Atlantic Ocean, with westerly maritime influences resulting in a plentiful supply of rainfall all year round (annual average precipitation is $1181 \mathrm{~mm}$ ), and a mild annual average temperature of $8.49^{\circ} \mathrm{C}$. It was chosen on the basis of observed erosion, with measured rates of deposition providing an opportunity for model validation under present-day conditions. Erosion at Loughmuck hillslope occurred (see Figs. 2 and 3) in October 2008 following heavy rainfall, where $33 \mathrm{~mm}$ fell over one 24 -h period and monthly rainfall totals reached levels 33\% higher than the long-term mean for October, and the coincident occurrence of this heavy rainfall with an unprotected surface following tillage to establish a new sward of grass, a practice which is repeated approximately once every ten years.

\subsection{WEPP parameterisation under present-day conditions}

WEPP(v.2008.907) requires a slope file, a soil file, a management file, and a climate file in order to simulate erosion for hillslopes or watersheds. The slope file was generated by using Differential Global Positioning Systems (DGPS) to acquire length and elevation data for Loughmuck hillslope. Three bulk soil samples to a $15 \mathrm{~cm}$ depth taken from the top, middle and bottom of the hillslope were averaged and then analysed in the laboratory with respect to properties including soil texture, organic matter, rock content and cation exchange capacity. Properties for lower soil depths were taken from Cruickshank (1997) following a soil survey of Northern Ireland between 1987 and 1997. Effective hydraulic conductivity, critical shear, and erodibility values were calculated using equations in the WEPP user manual (Flanagan and Livingston, 1995). The full list of soil properties for Loughmuck hillslope are displayed in Tables 2 and 3. Plant growth parameters for grass were taken directly from the WEPP plant database (Flanagan and Nearing, 1995), with a number of parameters altered by consulting values from Cruickshank (1997) to accord more closely with grass growth
Table 2

Soil properties obtained using both measured and secondary values.

\begin{tabular}{lccc}
\hline $\begin{array}{l}\text { Measured/sourced } \\
\text { soil properties }\end{array}$ & \multicolumn{3}{l}{ Soil horizon and depth $(\mathrm{cm})$} \\
\cline { 2 - 4 } & $\mathrm{Ap}(0-15)^{\mathrm{a}}$ & $\mathrm{Bw}(16-54)^{\mathrm{b}}$ & $\mathrm{C}(55-120)^{\mathrm{b}}$ \\
\hline Sand (\%) & 30.5 & 49.5 & 71.4 \\
Silt (\%) & 58.7 & 41.1 & 21.3 \\
Clay (\%) & 10.8 & 9.6 & 7.3 \\
Organic content (\%) & 2.68 & 0.78 & 0.2 \\
CEC (meq/100g) & 35.1 & 13.4 & 7.4 \\
Rock (\%) & 8.9 & 8.9 & 8.9 \\
\hline
\end{tabular}

a Measured values.

b Secondary values.

Table 3

Soil properties obtained using equations in the WEPP user manual.

\begin{tabular}{ll}
\hline WEPP calculated soil properties & Values \\
\hline Interrill erodibility $\left(\mathrm{Kg} \mathrm{s} \mathrm{m}^{-4}\right)$ & $3,506,684$ \\
Rill erodibility $\left(\mathrm{s} \mathrm{m}^{-1}\right)$ & 0.0033 \\
Critical shear $(\mathrm{Pa})$ & 3.14 \\
Effective hydraulic conductivity $\left(\mathrm{mm} / \mathrm{h}^{-1}\right)$ & 4.56 \\
\hline
\end{tabular}

Table 4

Parameterisation of the plant file for grass including changes from default WEPP values to accord more closely with Irish grass.

\begin{tabular}{lcc}
\hline Plant parameters & $\begin{array}{c}\text { WEPP } \\
\text { database }\end{array}$ & $\begin{array}{c}\text { Changed } \\
\text { value }\end{array}$ \\
\hline Initial canopy cover $(0-100 \%)$ & 50 & 3 \\
Days since last tillage & 165 & 107 \\
Days since last harvest & 165 & 102 \\
Initial interrill cover $(0-100 \%)$ & 20 & 16 \\
Cumulative rainfall since last tillage $(\mathrm{mm})$ & 300 & 473 \\
Biomass energy ratio $(\mathrm{kg} / \mathrm{MJ})$ & 30 & 15 \\
Base daily air temperature $\left({ }^{\circ} \mathrm{C}\right)$ & 5 & 5.6 \\
Maximum temperature that stops the & 40 & 30 \\
$\quad$ growth of a perennial $\left({ }^{\circ} \mathrm{C}\right)$ & -20 & 0 \\
Critical freezing temperature for a & & \\
$\quad$ perennial crop $\left({ }^{\circ} \mathrm{C}\right)$ & &
\end{tabular}

in Ireland. In the initial conditions database, a number of parameters were changed based on running the WEPP model for a ten year simulation, with nine years of grass cover and tillage on the tenth year (Table 4). A climate file for Loughmuck hillslope was created using the WEPP weather generator CLIGEN, which constructs long sequences of climate data based upon the statistical properties of observed climate data (Nicks et al., 1995). Daily input data on maximum and minimum temperature, precipitation, wind speed and direction, dew point temperature, sub-hourly precipitation, and solar radiation are required to construct an input file for CLIGEN. Most of these variables were taken from a nearby climatological station, ca. $10 \mathrm{~km}$ from Loughmuck hillslope. In the absence of all meteorological variables from a single climatological station, parameters on sub-hourly rainfall intensity and solar radiation were taken from two different climatological stations, further from the field site (ca. $15 \mathrm{~km}$ and $100 \mathrm{~km}$, respectively). Using CLIGEN, 300 years of climate data for Loughmuck hillslope were generated, which was subsequently used to run WEPP for a 300 year simulation under present-day conditions, providing a baseline against which simulations under future climate change could be compared. The length of simulation was chosen to allow a sufficient number of till-no-till cycles to be modelled (30 tillage years, 270 no-till years). This represents the long-term average annual erosion rate, accounting for erosion during the one tillage year occurring once every ten years, as well as the remaining nine no-till years of the cycle. 


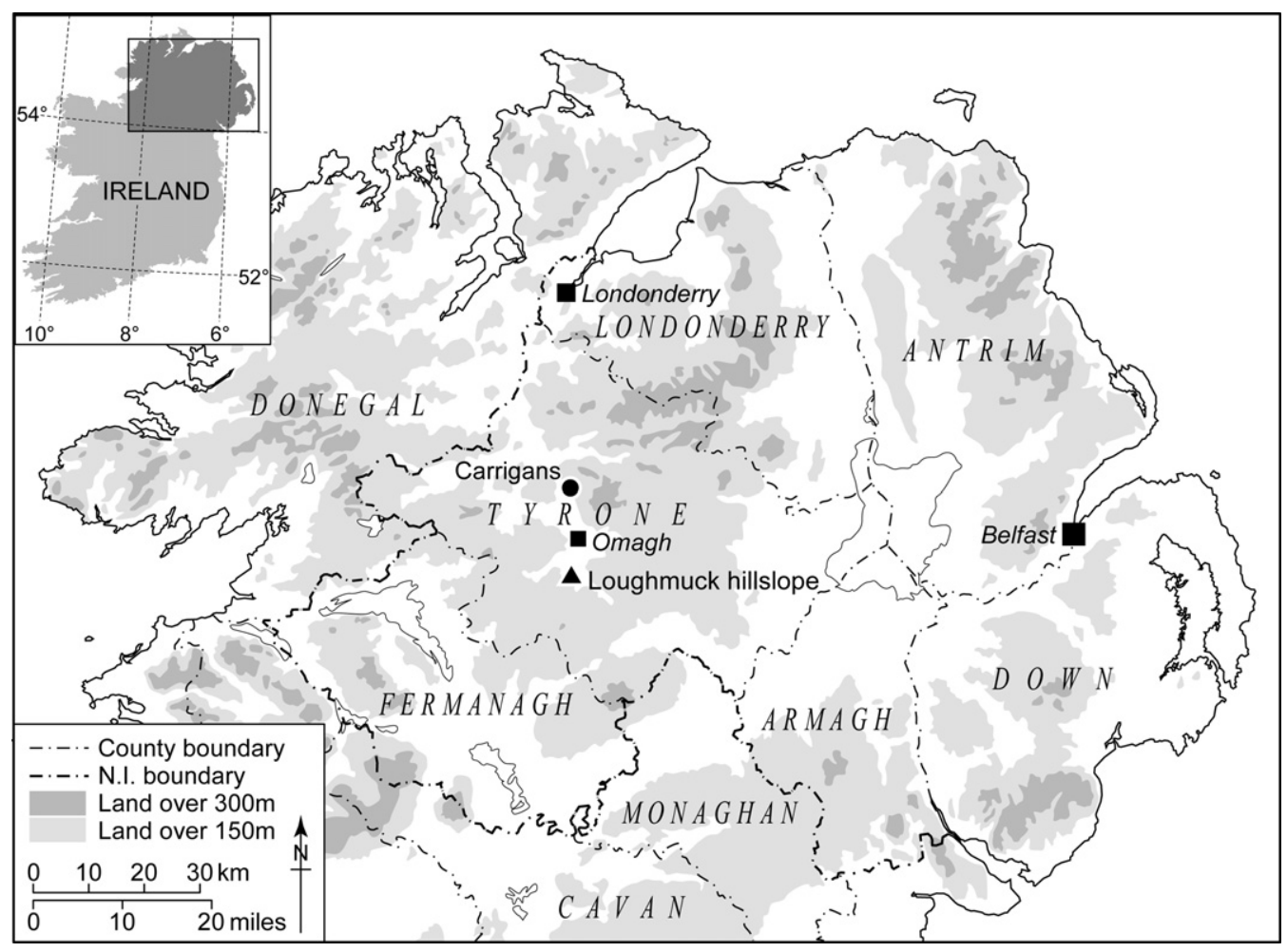

Fig. 1. Location of the case study hillslope.
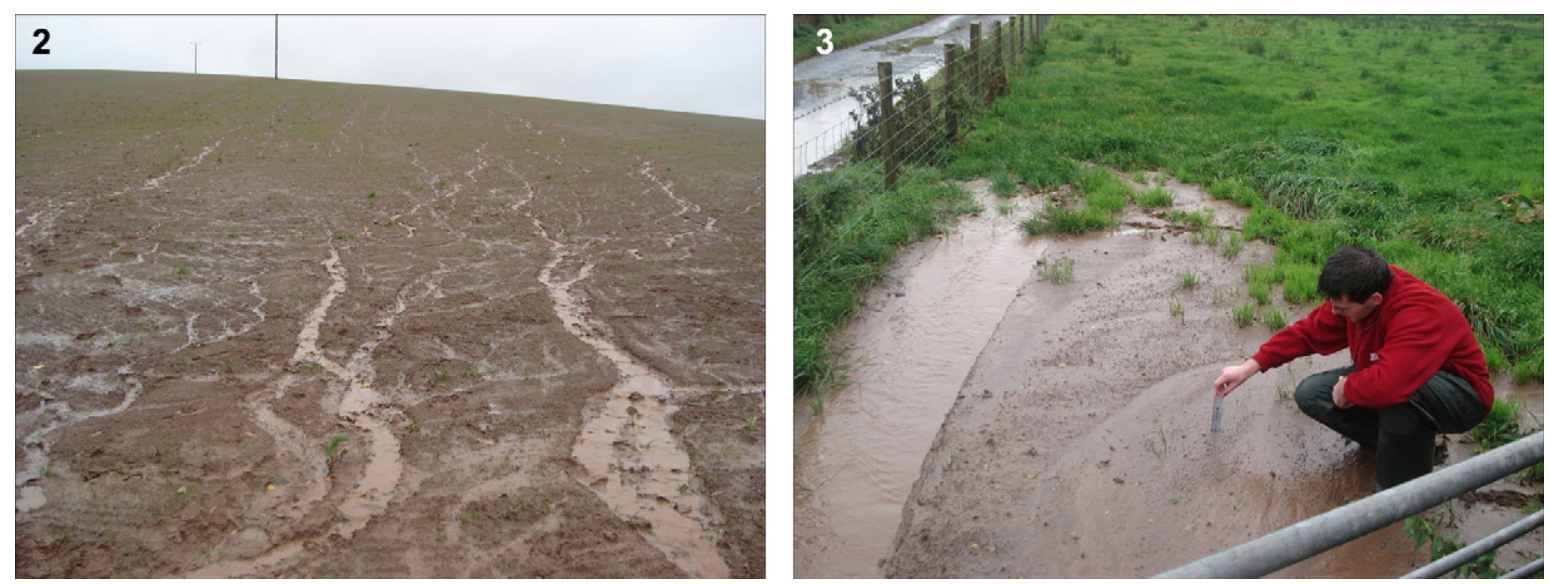

Figs. 2 and 3. Rills and deposition at Loughmuck hillslope following erosion in October 2008.

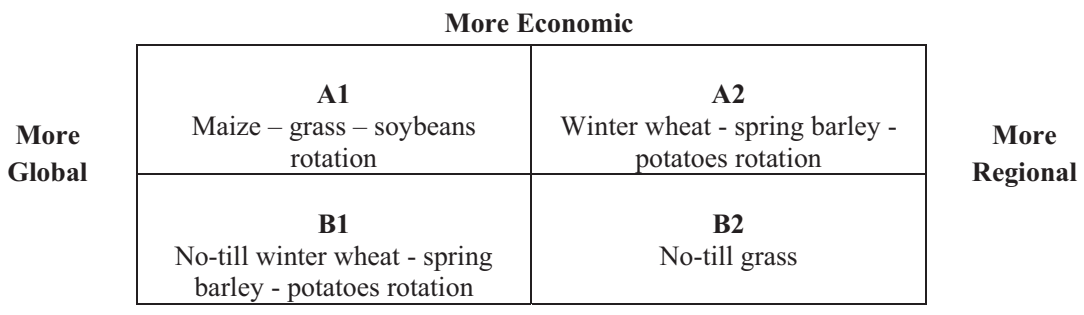

More Environmental

Fig. 4. Four specific future land use scenarios selected under the four alternative socio-economic futures as outlined by SRES.

\subsubsection{Model validation approach}

Since there are no measurements of soil erosion available anywhere on the island of Ireland, a pragmatic approach to support model validation was taken in this study, using whatever primary data could be gathered in conjunction with analogue approaches that made use of measurements made in comparable landscapes. Approximate measurements of a depositional fan at the base of the hillslope (Fig. 3) following the erosion event described in Section 3.1 
and subsequent volumetric calculations provided an estimate of the amount of soil eroded from the hillslope. These measurements provided an estimated rate of present-day soil erosion against which present-day model simulations could be compared. In order to achieve this comparison, the 30 tillage years from the same 300 year simulation described above were extracted and averaged, giving an average annual erosion rate during tillage years only. Since measured rates of deposition for this hillslope were obtained during a year in which tillage occurred, the modelled average annual erosion rate during the 30 tillage years of the 300 year simulation should be broadly comparable with the measured rate, and thus provide a means of model validation. It is acknowledged, however, that this approach to model validation is subject to a number of potential limitations. Firstly, since it is deposition that was measured, this does not necessarily equate to the total amount of sediment eroded, and is likely to be an underestimation since some material is likely to have been redistributed across the hillslope and thus not have ended up in the main depositional fan. In addition, this method assumes that the measured erosion event is typical of erosion rates during tillage years. However, an episodic erosion event of this nature may not be representative of typical erosion rates during tillage years, as this particular event may have been larger or smaller than an average erosion event. Due to the absence of long-term measurement data, it is impossible to determine how representative this event is of long-term erosion rates during tillage years. However, despite these range of limitations, the measurements made here following a single erosion event at least provide a 'ball park' figure for local erosion rates during tillage years. In addition to comparing the present-day simulated soil erosion rate with the local measurements described above, a comparison with soil erosion measurements made in Britain for individual events and over longer time periods was also made. These analogue measurements, although not directly comparable with Loughmuck hillslope, provide a range of soil erosion rates under broadly similar conditions.

\subsection{WEPP parameterisation under future conditions}

\subsubsection{Generating changed climate data}

Statistical downscaling methods were used to generate sitespecific future climate change projections as input to WEPP. Statistical downscaling methods rely on identifying and developing mathematical transfer functions or empirical relationships between observed large-scale predictors and the surface environmental variable of interest (local scale predictands) (Wilby and Dawson, 2007). The Statistical DownScaling Model (SDSM) (Wilby and Dawson, 2007) was the specific model used. SDSM facilitates the rapid development of multiple, low-cost single-site scenarios of daily surface weather variables under present and future climate forcing (Wilby and Dawson, 2007). Three climate variables (predictands) were downscaled in this study to represent changed climate conditions. Observed daily maximum and minimum temperature, and daily precipitation data from a climate station (Carrigans) near Loughmuck hillslope for the period 1961-1990 were individually examined for strength of correlation with a set of large-scale daily predictors for the same period using National Centre for Environmental Prediction (NCEP) reanalysis predictor variables. Mathematical transfer functions were developed between each predictand and a selection of large-scale predictors most strongly correlated to them. Then, the predictor-predictand relationships established for the present-day were 'forced' under the guidance of the same set of selected predictors as output by GCMs for the future (1961-2099). Here, output from three GCMs and two emissions scenarios (Table 5) were used to downscale maximum and minimum temperature and precipitation in order to represent changed climatic conditions for WEPP. In addition, SDSM was used to create three separate ensembles for each GCM-emissions scenario combination, with each ensemble considered equally plausible scenarios realised by a common set of large-scale predictors (Wilby and Dawson, 2007). Use of multiple GCMs, emissions scenarios and ensembles helps address uncertainties inherent in climate models (Fealy and Sweeney, 2008). These future scenarios were then split into three future time slices centred on the 2020s (2011-2040), 2050s (2041-2070) and 2080s (2071-2099), and input to the WEPP weather generator CLIGEN to represent perturbed climate data. With results for three ensembles from three GCMs and two emissions scenarios, and for three future time slices, a total of 54 future downscaled climate change scenarios were produced (Table 9). A key advantage to the use of SDSM, and in contrast to many other statistical downscaling methods including those employed by Zhang et al. (2004), is that its daily temporal resolution removes the requirement for temporal downscaling from a monthly resolution. This addresses the problem of how to attribute precipitation change to number of wet days and precipitation amount on a wet day, since these parameters are easily calculated from future daily output in the same way as for present-day daily data. The method fails, however, to capture sub-daily future climate information and provide a handle on rainfall intensity at finer temporal scales, to provide perturbed climate data for WEPP intensity parameters such as MX.5P. In the absence of any robust method, sensitivity analysis is used here to represent sub-daily future rainfall intensity characteristics, by applying $10 \%, 20 \%$ and $50 \%$ increases evenly across all months of the year. It is accepted that this methodology is almost entirely unrealistic, but at least considers a previously neglected issue.

\subsubsection{Changed land use and management data}

Owing to the difficulty in objectively projecting future changes in land use, a scenarios-based methodology is employed here, based upon the Special Report on Emissions Scenarios (SRES) (Nakicenovic and Swart, 2000). The SRES was developed in the Intergovernmental Panel on Climate Change (IPCC) Third Assessment Report (TAR), characterising a range of different future greenhouse gas emissions that would result from four alternative socio-economic futures (Parry, 2002). The SRES approach and the four alternative socio-economic futures are described in Table 6. Translating these four pathways into specific future land use scenarios was conducted subjectively by determining potential specific land cover types to accord with the characteristics of each of the four alternative socio-economic futures. For example, the environmental emphasis surrounding the B1 and B2 scenarios prompted specific land use changes towards the adoption of no-till management practices. Parts of Northern Ireland in the present-day fall under the Environmentally Sensitive Areas Designation Order (2005), whereby farmers are prohibited from tillage practices in order to qualify for subsidy payments. If parts of Northern Ireland are already adopting no-till practices in the present-day, then it seems plausible that the land under this legislation may increase under future world development pathways involving heightened environmental awareness. In contrast, a more economic future under the A1 and A2 scenarios may lead to an increase in highfodder crops for livestock such as maize and soybeans, and cereals such as wheat and barley, in order to support increased meat and cereals demand due to population growth. A total of four land use scenarios representing each of the four alternative socio-economic pathways were constructed in this manner, as displayed in Fig. 4. It is acknowledged that this is an over-simplistic approach to projecting future land use change, as patterns of land use, land cover change and land management are shaped by the interaction of economic, environmental, social, political, and technological forces on local to global scales, with most authors highlighting the case of policies as of significant importance in driving land use changes (Lambin et al., 2001). Nonetheless, the approach outlined here, 
Table 5

Details of the GCMs used in this study.

\begin{tabular}{|c|c|c|c|}
\hline GCM & Organisation & Country & Key reference \\
\hline HadCM3 & UK Met Office Hadley Centre & UK & Gordon et al. (2000) \\
\hline CGCM2 & Canadian Centre for Climate Modelling and Analysis & Canada & Flato et al. (2000) \\
\hline CSIROMk2 & Australian Commonwealth Scientific and Research Organisation & Australia & Gordon and O'Farrell (1997) \\
\hline
\end{tabular}

Table 6

Key characteristics of the four SRES families (after Nakicenovic and Swart, 2000).

Scenario Key characteristics
family

A1 Very rapid economic growth with increasing globalisation, increased wealth, reduced convergence between regions and reduced disparities in regional per capita income. They emphasise market-orientated solutions, high consumption of commodities, and advanced technology and communications. The three variants within the A1 family make different assumptions about sources of energy for this rapid growth, with fossil-intensive (A1F1), non-fossil fuels (A1T) or a balance across all sources (A1B).

A2 Heterogeneous, market-led world, with less rapid economic growth than A1, but increased population growth due to less convergence of fertility rates. Self-reliance and less emphasis on economic, social and cultural interactions between regions characterise this family. Economic growth is uneven, and the income gap between the developed and developing world does not narrow.

B1 Characterised by a high level of environmental and social consciousness, combined with a globally coherent approach towards a more sustainable development. Governments, businesses and the media pay increased attention to the environmental and social aspects to development, reflected by increased emphasis on clean, renewable technologies.

B2 Increased concern for environmental and social sustainability, where government policies and business strategies at national and local levels are influenced by environmental awareness and a trend towards self-reliance and stronger communities. based upon a range of alternative pathways of world development and their likely impact on local land use policies, represents a range of potential future scenarios, grounded within a sensible framework of future pathways of world development. In addition to land use changes, dates of planting and harvesting were also changed for each future time slice. These changes were made according to the length of the growing season, by examining the threshold temperature required for growth of whatever $\operatorname{crop}(\mathrm{s})$ were involved in the rotation. For example, the threshold temperature for grass growth is $5.6^{\circ} \mathrm{C}$ in Northern Ireland (Betts, 1997), which under the present-day is exceeded 206 days in the year. Calculating the number of days per year this same threshold temperature is exceeded for the future was then conducted for each GCM and emissions scenario and averaged for each time slice. For grass, this resulted in 248 days for the 2020s, 263 days for the 2050s and 277 days for the 2080s. The difference in the number of days between the present-day and future time slices was then split in half, delaying tillage and planting by half the number of extra growing days, and bringing harvesting forward by half the amount of growing days, as illustrated for grass in Table 7. Since each crop has a different threshold temperature for growth, this had to be repeated for all crops involved in the analysis. As with the approach to developing future land use changes, this approach to changing planting and harvesting dates is over-simplistic, since other factors including precipitation and its effects on soil moisture also play a role in governing changes in the length of the growing season (Betts, 1997). Nonetheless, using the threshold temperature approach as
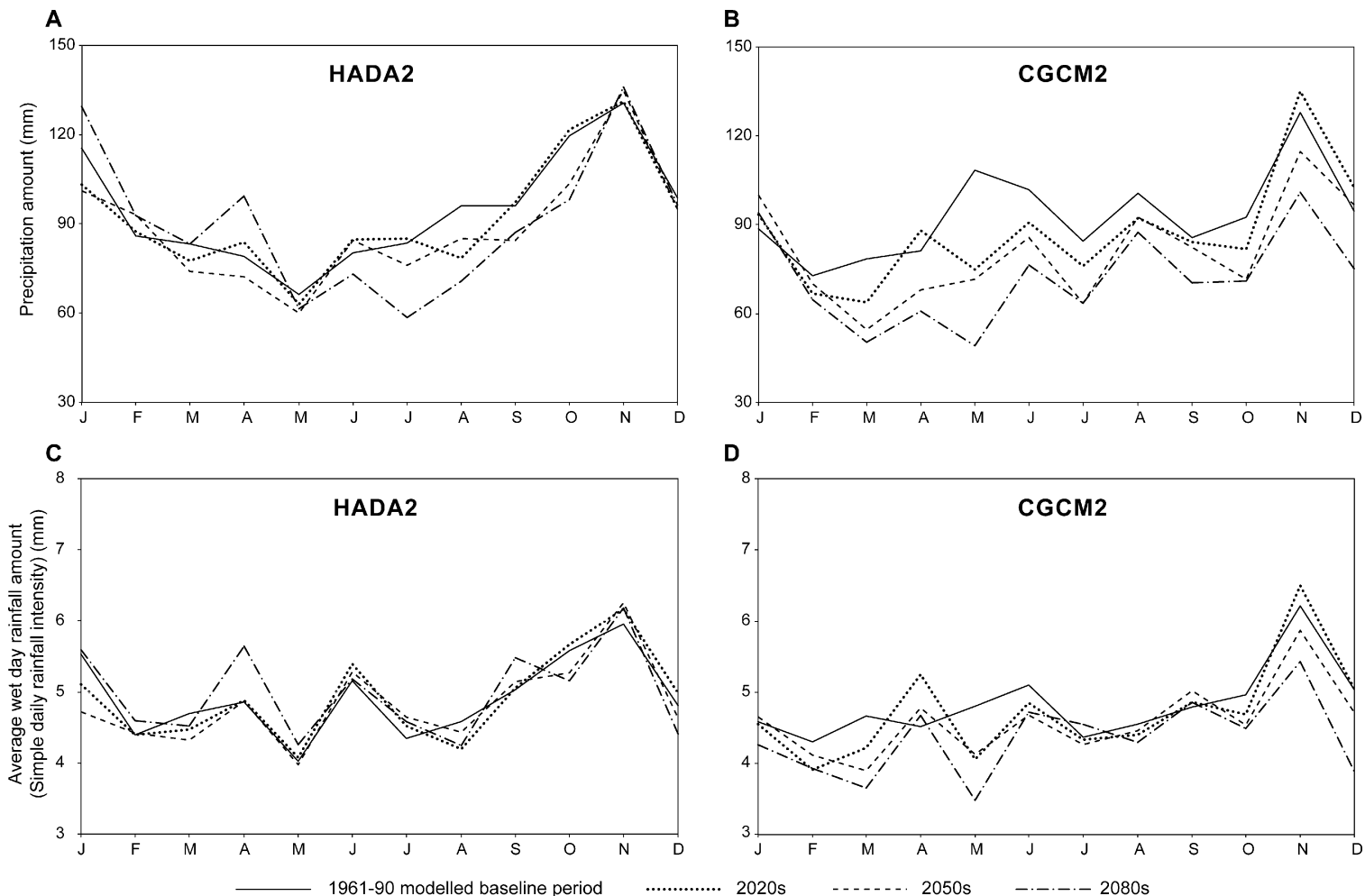

D

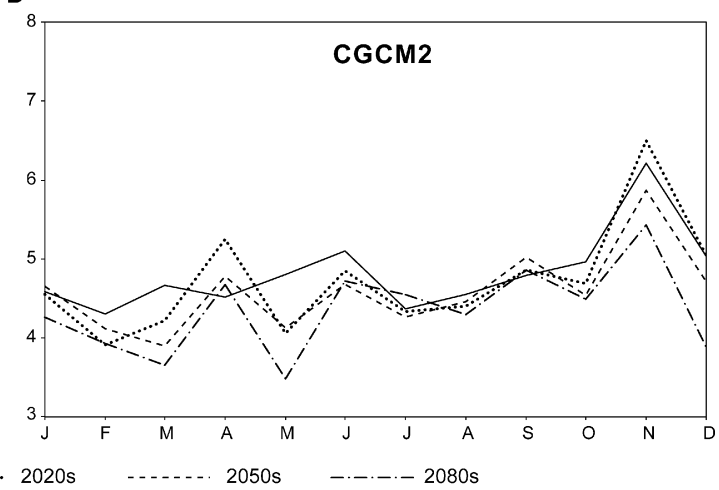

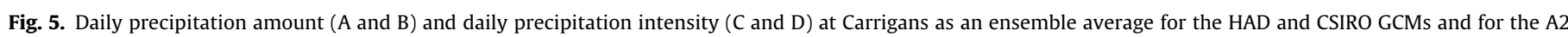
emissions scenario. 
Table 7

Illustration of the methods used to change planting and harvesting dates under future land use and management scenarios.

\begin{tabular}{llll}
\hline \multirow{2}{*}{ Scenario } & \multicolumn{3}{l}{ Growing degree days } \\
\cline { 2 - 4 } & $2020 \mathrm{~s}$ & $2050 \mathrm{~s}$ & $2080 \mathrm{~s}$ \\
\hline HAD A2 & 235 & 254 & 276 \\
HAD B2 & 242 & 249 & 259 \\
CGCM A2 & 247 & 270 & 282 \\
CGCM B2 & 250 & 258 & 270 \\
CSIRO A2 & 253 & 271 & 295 \\
CSIRO B2 & 259 & 273 & 277 \\
Scenario mean & 248 & 263 & 277 \\
Present day & 206 & 206 & 206 \\
Difference in days & 42 & 57 & 71 \\
No. days planting delayed & $\mathbf{2 1}$ & $\mathbf{2 9}$ & $\mathbf{3 6}$ \\
No. days harvest brought forward & $\mathbf{2 1}$ & $\mathbf{2 8}$ & $\mathbf{3 5}$ \\
\hline
\end{tabular}

Table 8

Measured and modelled rates of erosion and deposition for Loughmuck hillslope.

\begin{tabular}{lll}
\hline $\begin{array}{l}\text { Long-term average } \\
\text { annual rate (t/ha) }\end{array}$ & $\begin{array}{l}\text { Average annual } \\
\text { rate for tillage } \\
\text { years only }(\mathrm{t} / \mathrm{ha})\end{array}$ & $\begin{array}{l}\text { Measured deposition } \\
\text { rate }(\mathrm{t} / \mathrm{ha})\end{array}$ \\
\hline 0.61 & 5.92 & $4.55(3.42-6.83)$ \\
\hline
\end{tabular}

outlined above, at least provides an indication of possible changes to the dates of future farming operations.

\section{Results and discussion}

\subsection{Model validation}

Table 8 displays the modelled long-term average annual erosion rate, and also compares the modelled short-term average annual erosion rate (tillage years only) with measured rates of deposition. The measured soil erosion rate of $4.55 \mathrm{t} / \mathrm{ha}$ compares closely with the short-term modelled erosion rate of $5.92 \mathrm{t} / \mathrm{ha}$, and lies within the uncertainty bands surrounding the measured rate (3.42-6.83 t/ha). As described in Section 3.1, these uncertainty bands arise from the relative subjectivity in allocating the contributing area of the field to erosion, where hillslope length is easily delineated, but hillslope width is more subjective. In addition, analogue erosion measurements from individual erosion events similar to that described in this study reveal erosion rates encompassing those from Loughmuck hillslope. Erosion rates from these analogue studies range from $0.2 \mathrm{t} /$ ha in Shropshire, western England to $195 \mathrm{t} /$ ha in Norfolk, eastern England. Of those studies in Britain with measured erosion rates, however, the measured rates from Angus, eastern Scotland are perhaps most analogous to the event described here. In that particular study, Kirkbride and Reeves (1993) describe erosion on three reseeded grass fields following $55 \mathrm{~mm}$ of rainfall over a 24-h period on 31st March 1992. With a similar soil texture (loam and sandy loam soils in Angus compared to silt loam at Loughmuck) and an almost identical set of circumstances leading to the erosion event, soil erosion rates at these three Scottish locations should be broadly comparable to those at Loughmuck hillslope. Measured rates of $1.17 \mathrm{t} /$ ha, $1.73 \mathrm{t} /$ ha and $2.22 \mathrm{t} /$ ha fall below those measured at Loughmuck hillslope, but still represent rates within the same order of magnitude. Over a two year period in north-east Scotland, Watson and Evans (1991) measured individual erosion rates at 30 locations under land use ranging from winter cereals to reseeded grass, with soil loss rates ranging from 0.2 to $39.3 \mathrm{t} / \mathrm{ha}$, and a mean rate of $7.8 \mathrm{t} / \mathrm{h}$. The measured rate from Loughmuck hillslope falls within this range and compares closely to the mean rate. Since these measured rates of erosion from Scotland represent rates for individual events in the same manner as those from Loughmuck hillslope, however, they fail to offer any information on how typical these rates are of long-term erosion. In order to gain some indication on longer-term erosion rates, results from 1705 arable and reseeded grass fields in 17 locations across England and Wales over a 5 year period (Evans, 1993) were examined. With a mean measured rate of $3 \mathrm{t} / \mathrm{ha}$, ranging between 0.13 and $5.46 \mathrm{t} / \mathrm{ha}$, these rates of soil erosion are again broadly comparable with those from Loughmuck hillslope. Owing to the lack of long-term local measurements and problems of direct comparability between local measured erosion rates with those from Britain, conclusions from the validation approach used in this study must be made with caution, but at least provides a crude means of assessing model performance under present-day conditions.

\subsection{Future erosion rates}

Future erosion rates are displayed as percentage changes from the present-day baseline erosion rate. Results are provided for future erosion rates under four distinct combinations of scenarios, or groups, as displayed in Table 9.

\subsubsection{Group A scenarios}

Table 10 and Fig. 6(a) illustrates future rates of soil erosion under Group A scenarios at Loughmuck hillslope. The average of the three ensembles, three GCMs and two emissions scenarios reveal soil erosion decreases from the baseline rate of $0.61 \mathrm{t} / \mathrm{ha}$ of between $-48 \%$ ( $0.31 \mathrm{t} / \mathrm{ha})$ for the $2020 \mathrm{~s}$ and $-61 \%$ (0.24t/ha) for the $2080 \mathrm{~s}$. The inter-scenario range illustrates a wide discrepancy between individual scenarios for all three future time slices, ranging from decreases of $93 \%$ ( $0.04 \mathrm{t} / \mathrm{ha}$ ) to increases of $10 \%$ ( $0.67 \mathrm{t} / \mathrm{ha}$ ), although with only two of the 54 scenarios revealing soil erosion increases, the general trend under Group A scenarios is towards decreased soil erosion rates. Precipitation decreases of between $5 \%$ and $31 \%$ across the same 54 scenarios illustrate the key factor responsible for reducing soil erosion rates. Critically, however, it is the timing of precipitation and the amount of precipitation per wet day (daily precipitation intensity) rather than merely the average annual precipitation amount that generally controls the response of erosion to climate change. The 'window of opportunity' when tillage occurs once every ten years is 'opened' in the autumn months. Therefore, it is precipitation amount and daily precipitation intensity during these months (Fig. 5) that impact erosion rates most. The HAD and CGCM models particularly illustrate this trend, with an increase in precipitation amount in the autumn and winter months, compared with the rest of the year, consequently resulting in generally higher soil erosion rates as opposed to results from the CSIRO model. In addition, daily precipitation intensity increases during these key autumn months when compared to the observed baseline daily intensity rate. This explains why increases in runoff rates can occur even when average annual precipitation decreases. Indeed the maximum increase in runoff from any of the future scenarios (99\%) occurs at a time when average annual precipitation decreases by $7 \%$. This highlights the role seasonal variation in precipitation and daily precipitation intensity play in impacting future rates of soil erosion, illustrating the need to look beyond average annual precipitation amount.

\subsubsection{Group B scenarios}

Table 11 and Fig. 6(b) exhibit the response of the average annual erosion rate at Loughmuck hillslope under Group B scenarios. Changes in soil erosion rates generally reflect the magnitude of the sub-daily rainfall intensity changes. For example, $10 \%$ increases in sub-daily rainfall intensity generally result in soil erosion decreases, with GCM-emissions scenario combinations averaging between $32 \%$ decreases ( $0.42 \mathrm{t} / \mathrm{ha}$ ) for the 2050 s and $58 \%$ decreases ( $0.25 \mathrm{t} / \mathrm{ha}$ ) for the $2080 \mathrm{~s}$, and individual scenarios ranging between 
Table 9

The four scenario groups of future soil erosion rates for Loughmuck hillslope.

\begin{tabular}{|c|c|c|c|c|c|c|c|}
\hline \multirow[t]{2}{*}{ Group } & \multicolumn{3}{|c|}{ Downscaled climate change scenarios } & \multirow{2}{*}{$\begin{array}{l}\text { Rainfall intensity } \\
\text { changes }\end{array}$} & \multirow{2}{*}{$\begin{array}{l}\text { Land use } \\
\text { scenarios }\end{array}$} & \multirow[t]{2}{*}{ Time slices } & \multirow{2}{*}{$\begin{array}{l}\text { Total } \\
\text { scenarios }\end{array}$} \\
\hline & GCMs & Emissions & Ensembles & & & & \\
\hline A & 3 & 2 & 3 & - & - & 3 & 54 \\
\hline B & 3 & 2 & 1 & 3 & - & 3 & 54 \\
\hline C & 3 & 2 & 1 & - & 4 & 3 & 72 \\
\hline $\mathrm{D}$ & 3 & 2 & 1 & 3 & 4 & 3 & 216 \\
\hline
\end{tabular}

Group A: downscaled climate change scenarios;

Group B: downscaled climate change scenarios + sub-daily rainfall intensity changes;

Group C: downscaled climate change scenarios + land use and management scenarios;

Group D: downscaled climate change scenarios + sub-daily rainfall intensity changes + land use and management scenarios.

93\% decreases ( $0.04 \mathrm{t} / \mathrm{ha})$ and $5 \%$ increases ( $0.64 \mathrm{t} / \mathrm{ha})$. In contrast, $50 \%$ increases in sub-daily rainfall intensity generally result in soil erosion increases, with GCM-emissions scenario combinations averaging between a $1 \%$ decrease $(0.61 \mathrm{t} / \mathrm{ha})$ for the 2080 s and a $37 \%$ increase $(0.84 \mathrm{t} / \mathrm{ha})$ for the $2050 \mathrm{~s}$, with individual scenarios ranging between $57 \%$ decreases ( $0.26 \mathrm{t} / \mathrm{ha})$ and $134 \%$ increases $(1.43 \mathrm{t} / \mathrm{ha})$. As the sub-daily rainfall intensity changes are constant for all scenarios and are built upon the downscaled climate change scenarios from Group A, variations in erosion rates under these future scenarios reflect the same set of factors responsible for variations under the downscaled climate change scenarios, as well as the magnitude of the rainfall intensity changes. This explains why even with $50 \%$ increases in sub-daily rainfall intensity, soil erosion decreases can occur.

\subsubsection{Group C scenarios}

Tables 12 and 13 and future rates of soil erosion under Group C scenarios are presented in Fig. 6(c). Large increases are projected under two of the four land use scenarios (A1 and A2). For example, average increases across GCMs and emissions scenarios of between $745 \%$ (5.2 t/ha) for the 2080s and $1079 \%$ (7.2 $\mathrm{t} / \mathrm{ha}$ ) for the 2020s are projected under the A1 land use scenario, with between $275 \%$ ( $2.3 \mathrm{t} / \mathrm{ha}$ ) and $328 \%$ increases ( $2.6 \mathrm{t} / \mathrm{ha}$ ) for the $2080 \mathrm{~s}$ and 2050s respectively projected for the A2 land use scenario. Individual GCM-emissions scenario combinations range between
$52 \%$ increases ( $0.93 \mathrm{t} / \mathrm{ha}$ ) and $1816 \%$ increases ( $11.7 \mathrm{t} / \mathrm{ha}$ ) in soil erosion for the same two land use scenarios. Under these new arable rotations, such large increases in erosion can be attributed to the extension of the one-in-ten-year 'window of opportunity' to an annual window with tillage occurring every autumn and thereby leaving the soil exposed at a time when daily rainfall intensity is highest. Under the B1 land use scenario, mixtures of increases and decreases are projected, ranging between $-67 \%(0.2 \mathrm{t} / \mathrm{ha})$ and $+97 \%$ ( $1.2 \mathrm{t} / \mathrm{ha}$ ). Increases under B1 can be attributed to the arable rotation where reduced land cover following planting reduces protection of the soil surface, with decreases reflecting the adoption of no-till as part of the land use scenario. The B2 land use scenario results in considerable soil erosion decreases, ranging between $-72 \%(0.17 \mathrm{t} / \mathrm{ha})$ and $-100 \%$. These decreases reflect the protection afforded to the soil by the grass cover and the implementation of no-till land management.

\subsubsection{Group D scenarios}

Future rates of soil erosion under Group D scenarios (Fig. 6(d)) reveal the largest increases in soil erosion rates. Averaged across all GCMs, emissions scenarios, rainfall intensity changes and land use scenarios, large soil erosion increases between $481 \%$ ( $3.5 \mathrm{t} / \mathrm{ha})$ for the 2080 s and $628 \%$ (4.4t/ha) for the 2020 s are projected. Within this averaging of scenarios, however, a huge gulf in changing soil

Table 10

Changes in average annual precipitation, runoff and soil erosion as an average of the Group A scenarios.

\begin{tabular}{|c|c|c|c|c|c|c|}
\hline Scenario & $\begin{array}{l}\text { Precipitation } \\
\text { depth }(\mathrm{mm})\end{array}$ & $\%$ Change & $\begin{array}{l}\text { Runoff depth } \\
(\mathrm{mm})\end{array}$ & $\%$ Change & $\begin{array}{l}\text { Average annual } \\
\text { soil loss (t/ha) }\end{array}$ & $\%$ Change \\
\hline Baseline & 1200 & 0 & 1.04 & 0 & 0.61 & 0 \\
\hline \multicolumn{7}{|l|}{$2020 s$} \\
\hline HADA2 & 1110 & -8 & 1.29 & 24 & 0.32 & -48 \\
\hline CGCMA2 & 1027 & -14 & 0.84 & -20 & 0.29 & -52 \\
\hline CSIROA2 & 1083 & -10 & 0.67 & -36 & 0.27 & -56 \\
\hline HADB2 & 1138 & -5 & 1.33 & 28 & 0.44 & -28 \\
\hline CGCMB2 & 1079 & -10 & 0.78 & -25 & 0.26 & -57 \\
\hline CSIROB2 & 1025 & -15 & 0.46 & -55 & 0.30 & -50 \\
\hline Mean & 1077 & -10 & 0.89 & -14 & 0.31 & -48 \\
\hline \multicolumn{7}{|l|}{ 2050s } \\
\hline HADA2 & 1068 & -11 & 0.82 & -21 & 0.31 & -49 \\
\hline CGCMA2 & 970 & -19 & 0.82 & -21 & 0.42 & -31 \\
\hline CSIROA2 & 978 & -18 & 0.61 & -41 & 0.33 & -46 \\
\hline HADB2 & 1103 & -8 & 1.07 & 3 & 0.33 & -46 \\
\hline CGCMB2 & 1015 & -15 & 0.68 & -35 & 0.26 & -58 \\
\hline CSIROB2 & 1049 & -13 & 0.40 & -62 & 0.15 & -75 \\
\hline Mean & 1031 & -14 & 0.73 & -29 & 0.30 & -51 \\
\hline \multicolumn{7}{|l|}{ 2080s } \\
\hline HADA2 & 1089 & -9 & 1.33 & 28 & 0.26 & -57 \\
\hline CGCMA2 & 848 & -29 & 0.46 & -55 & 0.27 & -56 \\
\hline CSIROA2 & 948 & -21 & 0.27 & -74 & 0.19 & -68 \\
\hline HADB2 & 1123 & -6 & 1.24 & 19 & 0.33 & -46 \\
\hline CGCMB2 & 986 & -18 & 0.43 & -59 & 0.22 & -64 \\
\hline CSIROB2 & 991 & -17 & 0.40 & -62 & 0.16 & -73 \\
\hline Mean & 998 & -17 & 0.69 & -34 & 0.24 & -61 \\
\hline
\end{tabular}


Table 11

Changes in average annual precipitation, runoff and soil erosion as an average of the Group B scenarios.

\begin{tabular}{|c|c|c|c|c|c|c|}
\hline Scenario & $\begin{array}{l}\text { Precipitation } \\
\text { depth }(\mathrm{mm})\end{array}$ & $\%$ Change & $\begin{array}{l}\text { Runoff depth } \\
(\mathrm{mm})\end{array}$ & $\%$ Change & $\begin{array}{l}\text { Average annual } \\
\text { soil loss (t/ha) }\end{array}$ & $\%$ Change \\
\hline Baseline & 1200 & 0 & 1.04 & 0 & 0.61 & 0 \\
\hline \multicolumn{7}{|l|}{ 2020s } \\
\hline HADA2 & 1104 & -8 & 1.44 & 38 & 0.63 & 3 \\
\hline CGCMA2 & 1029 & -14 & 0.62 & -41 & 0.32 & -48 \\
\hline CSIROA2 & 1073 & -11 & 1.15 & 10 & 0.59 & -3 \\
\hline HADB2 & 1141 & -5 & 1.68 & 62 & 0.43 & -29 \\
\hline CGCMB2 & 1074 & -11 & 1.85 & 78 & 0.63 & 3 \\
\hline CSIROB2 & 1012 & -16 & 0.96 & -8 & 0.58 & -4 \\
\hline Mean & 1072 & -11 & 1.28 & 23 & 0.53 & -13 \\
\hline \multicolumn{7}{|l|}{$2050 s$} \\
\hline HADA2 & 1104 & -8 & 2.03 & 95 & 0.97 & 58 \\
\hline CGCMA2 & 972 & -19 & 1.72 & 66 & 0.83 & 36 \\
\hline CSIROA2 & 996 & -17 & 0.80 & -23 & 0.50 & -18 \\
\hline HADB2 & 1109 & -8 & 0.92 & -12 & 0.43 & -29 \\
\hline CGCMB2 & 1024 & -15 & 1.43 & 37 & 0.51 & -16 \\
\hline CSIROB2 & 1087 & -9 & 0.62 & -41 & 0.33 & -46 \\
\hline Mean & 1049 & -13 & 1.25 & 20 & 0.59 & -3 \\
\hline \multicolumn{7}{|l|}{$2080 s$} \\
\hline HADA2 & 1095 & -9 & 1.30 & 25 & 0.41 & -33 \\
\hline CGCMA2 & 847 & -29 & 0.73 & -30 & 0.59 & -4 \\
\hline CSIROA2 & 944 & -21 & 0.31 & -71 & 0.16 & -74 \\
\hline HADB2 & 1130 & -6 & 1.85 & 78 & 0.46 & -25 \\
\hline CGCMB2 & 985 & -18 & 0.67 & -35 & 0.36 & -40 \\
\hline CSIROB2 & 994 & -17 & 0.85 & -19 & 0.38 & -37 \\
\hline Mean & 999 & -17 & 0.95 & -9 & 0.39 & -36 \\
\hline
\end{tabular}

erosion rates exists, ranging between $100 \%$ decreases and $3621 \%$ increases (22.7 t/ha). Such wide discrepancies reflect the nature of the individual scenarios, whereby decreases generally occur under no-till land use scenarios and particularly when rainfall intensity changes are lower. The highest soil erosion increases occur owing to the combined effects of a switch to a land use scenario where tillage occurs every year and the new row crops take time to establish following planting, thereby providing reduced land cover, and large increases in sub-daily rainfall intensity occur to exploit the exposed soil.

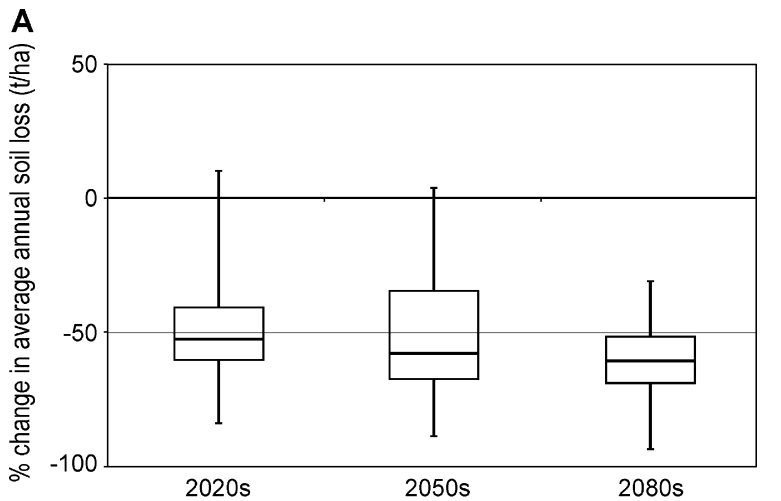

B
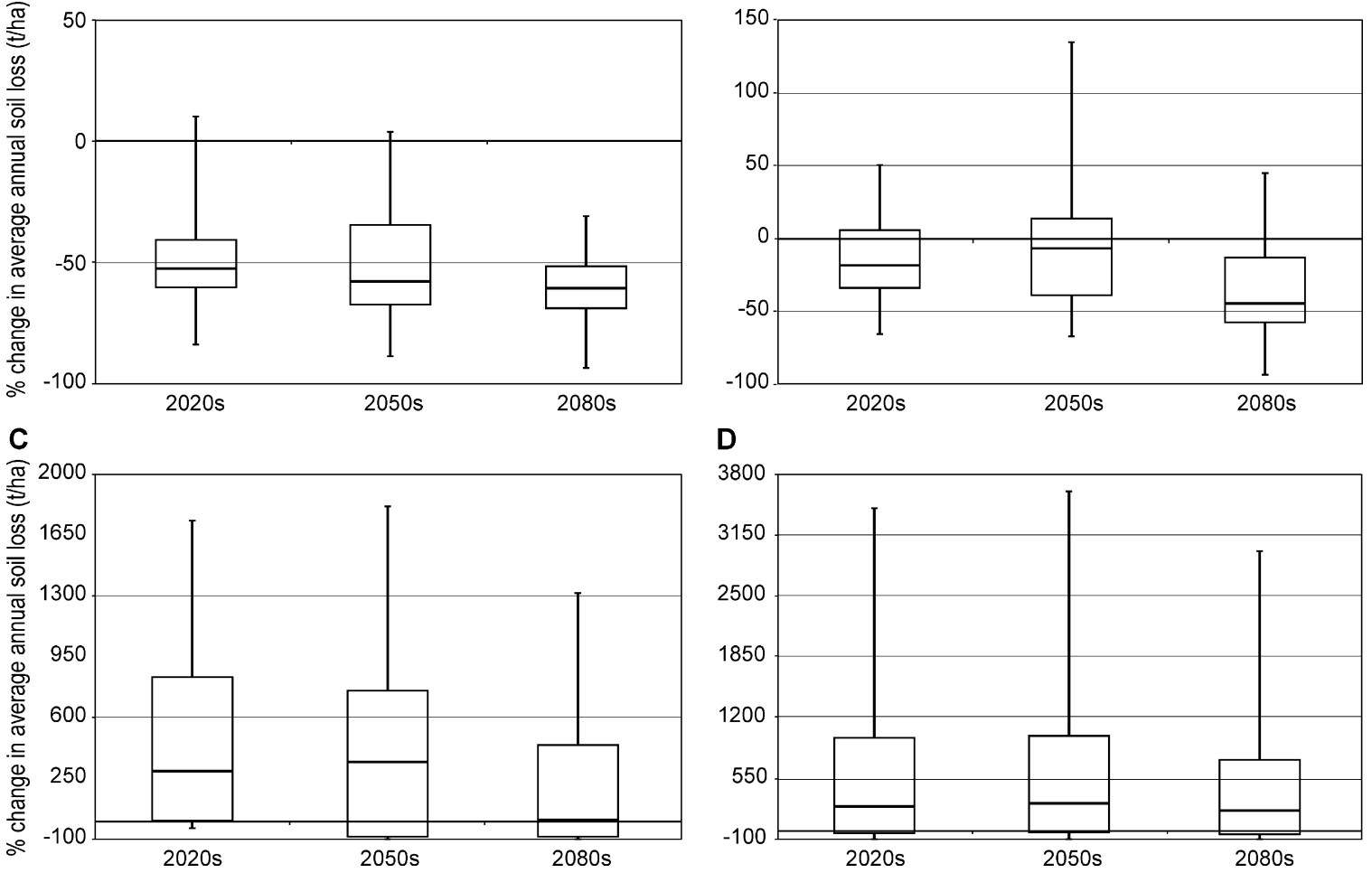

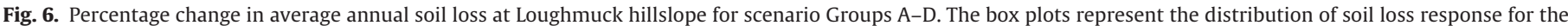

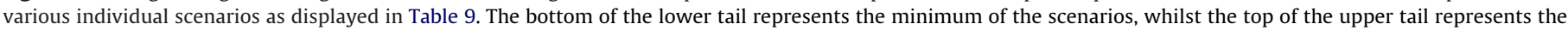

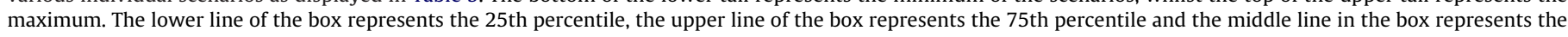
median. 
Table 12

Changes in average annual precipitation, runoff and soil erosion as an average of the Group C scenarios.

\begin{tabular}{|c|c|c|c|c|c|c|}
\hline Scenario & $\begin{array}{l}\text { Precipitation } \\
\text { depth }(\mathrm{mm})\end{array}$ & $\%$ Change & $\begin{array}{l}\text { Runoff depth } \\
(\mathrm{mm})\end{array}$ & $\%$ Change & $\begin{array}{l}\text { Average annual } \\
\text { soil loss (t/ha) }\end{array}$ & $\%$ Change \\
\hline Baseline & 1200 & 0 & 1.04 & 0 & 0.61 & 0 \\
\hline \multicolumn{7}{|l|}{$2020 s$} \\
\hline HADA2 & 1104 & -8 & 4.97 & 378 & 2.55 & 318 \\
\hline CGCMA2 & 1031 & -14 & 4.29 & 313 & 2.26 & 271 \\
\hline CSIROA2 & 1072 & -11 & 3.50 & 236 & 1.71 & 180 \\
\hline HADB2 & 1135 & -5 & 6.75 & 549 & 3.74 & 513 \\
\hline CGCMB2 & 1074 & -11 & 5.13 & 393 & 2.74 & 349 \\
\hline CSIROB2 & 1014 & -16 & 4.13 & 297 & 2.30 & 277 \\
\hline Mean & 1072 & -11 & 4.79 & 361 & 2.55 & 318 \\
\hline \multicolumn{7}{|l|}{ 2050s } \\
\hline HADA2 & 1106 & -8 & 7.86 & 656 & 4.19 & 586 \\
\hline CGCMA2 & 977 & -19 & 5.59 & 438 & 2.83 & 363 \\
\hline CSIROA2 & 997 & -17 & 3.53 & 239 & 1.87 & 207 \\
\hline HADB2 & 1107 & -8 & 5.22 & 401 & 2.63 & 331 \\
\hline CGCMB2 & 1025 & -15 & 4.49 & 331 & 2.28 & 274 \\
\hline CSIROB2 & 1087 & -9 & 3.67 & 253 & 1.88 & 209 \\
\hline Mean & 1050 & -13 & 5.06 & 386 & 2.61 & 328 \\
\hline \multicolumn{7}{|l|}{$2080 s$} \\
\hline HADA2 & 1094 & -9 & 6.46 & 521 & 3.16 & 418 \\
\hline CGCMA2 & 846 & -30 & 2.53 & 143 & 1.35 & 121 \\
\hline CSIROA2 & 947 & -21 & 1.79 & 72 & 0.86 & 40 \\
\hline HADB2 & 1131 & -6 & 6.77 & 550 & 3.23 & 429 \\
\hline CGCMB2 & 988 & -18 & 3.04 & 192 & 1.50 & 146 \\
\hline CSIROB2 & 991 & -17 & 3.77 & 262 & 2.08 & 240 \\
\hline Mean & 999 & -17 & 4.06 & 290 & 2.03 & 232 \\
\hline
\end{tabular}

Table 13

Changes in average annual precipitation, runoff and soil erosion as an average of the Group D scenarios.

\begin{tabular}{|c|c|c|c|c|c|c|}
\hline Scenario & $\begin{array}{l}\text { Precipitation } \\
\text { depth }(\mathrm{mm})\end{array}$ & $\%$ Change & $\begin{array}{l}\text { Runoff depth } \\
(\mathrm{mm})\end{array}$ & $\%$ Change & $\begin{array}{l}\text { Average annual } \\
\text { soil loss (t/ha) }\end{array}$ & $\%$ Change \\
\hline Baseline & 1200 & 0 & 1.04 & 0 & 0.61 & 0 \\
\hline \multicolumn{7}{|l|}{$2020 s$} \\
\hline HADA2 & 1104 & -8 & 8.61 & 728 & 4.81 & 688 \\
\hline CGCMA2 & 1031 & -14 & 7.29 & 601 & 4.27 & 601 \\
\hline CSIROA2 & 1072 & -11 & 6.20 & 496 & 3.42 & 460 \\
\hline HADB2 & 1135 & -5 & 9.79 & 842 & 5.54 & 808 \\
\hline CGCMB2 & 1074 & -11 & 8.28 & 696 & 4.69 & 668 \\
\hline CSIROB2 & 1014 & -16 & 6.59 & 534 & 3.93 & 543 \\
\hline Mean & 1072 & -11 & 7.79 & 649 & 4.44 & 628 \\
\hline \multicolumn{7}{|l|}{$2050 s$} \\
\hline HADA2 & 1106 & -8 & 11.25 & 981 & 6.25 & 925 \\
\hline CGCMA2 & 977 & -19 & 8.58 & 725 & 4.56 & 647 \\
\hline CSIROA2 & 997 & -17 & 5.75 & 453 & 3.38 & 453 \\
\hline HADB2 & 1107 & -8 & 8.81 & 747 & 4.99 & 719 \\
\hline CGCMB2 & 1025 & -15 & 7.06 & 579 & 3.66 & 500 \\
\hline CSIROB2 & 1087 & -9 & 5.38 & 417 & 3.02 & 395 \\
\hline Mean & 1050 & -13 & 7.80 & 650 & 4.31 & 606 \\
\hline \multicolumn{7}{|l|}{ 2080s } \\
\hline HADA2 & 1094 & -9 & 9.43 & 807 & 5.04 & 727 \\
\hline CGCMA2 & 846 & -30 & 4.48 & 330 & 2.56 & 320 \\
\hline CSIROA2 & 947 & -21 & 3.69 & 255 & 1.98 & 224 \\
\hline HADB2 & 1131 & -6 & 10.15 & 876 & 5.42 & 789 \\
\hline CGCMB2 & 988 & -18 & 5.49 & 428 & 2.88 & 371 \\
\hline CSIROB2 & 991 & -17 & 5.84 & 462 & 3.38 & 455 \\
\hline Mean & 999 & -17 & 6.51 & 526 & 3.54 & 481 \\
\hline
\end{tabular}

\section{Conclusions and implications}

Future rates of soil erosion may increase or decrease at Loughmuck hillslope, depending on the mix of factors considered. If downscaled climate change projections are considered in isolation, then future rates of soil erosion are generally projected to decrease due largely to decreases in precipitation amount. Increases in soil erosion are also projected in certain instances, however, even when precipitation decreases are projected, owing to the timing of precipitation to exploit the window of opportunity left by tillage, the precipitation variance, and the precipitation amount on wet days (i.e. daily precipitation intensity). When changes in sub-daily rainfall intensity and/or land use and management are added to the modelling process, however, then erosion rates are projected to either increase or decrease dramatically, depending on the specific scenarios. No-till land use scenarios and lower sub-daily rainfall intensity increases lead to generally large soil erosion decreases, whereas land use changes towards row crops requiring annual tillage together with large sub-daily rainfall intensity increases lead to generally very large increases in erosion rates.

Statistical downscaling of future climate change scenarios, as described in this study, represents a notable advance over those 
previous studies which considered only relative climate changes at the native GCM grid-box scale, and appears more appropriate for modelling future erosion rates than the more popular change factor approach for two main reasons. Firstly, it provides changes in climate variance as well as the mean climate. Secondly, the daily resolution of future output eliminates the problem of how to attribute precipitation change between number of wet days and precipitation amount on a wet day. Both these aspects permit a robust representation of site-specific future climate change scenarios, since they capture components of climate change with the potential to result in severe soil loss. The dramatic change in soil erosion rates owing to changes in sub-daily rainfall intensity and land use and management reveal the importance of considering these factors when modelling soil erosion under future climate change. Due to lack of confidence in rainfall projections developed at finer than daily temporal scales, and uncertainty surrounding changes in land use and management, however, these are also the factors that are currently the most difficult to project with any confidence and thus have not been considered in many previous studies. In the absence of any objective modelling framework, this study demonstrates how a simple sensitivity analysis approach for the former and a scenarios-based approach for the latter at least provide a handle on potential future changes that may accompany daily changes in climate. The development of more robust methodologies for both these aspects is a pressing research need for future studies. Since downscaled climate change scenarios in isolation generally project decreased future soil erosion rates, it is only through the inclusion of these additional factors that the hidden potential for increased soil erosion under future climate change in Northern Ireland was realised. This illuminates the need to address these key limitations, prevalent in many previous studies, if we are to robustly model future rates of soil erosion.

\section{References}

Anderson, J.N., 1997. Historical changes in epilimnetic phosphorus concentrations in six rural lakes in Northern Ireland. Freshwater Biology 38, $427-440$.

Betts, N.L., 1997. Climate. In: Cruickshank, J.G. (Ed.), Soil and Environment: Northern Ireland. Department of Agriculture for Northern Ireland and Queen's University Belfast, Belfast, pp. 63-84.

Boardman, J., 2010. A short history of muddy floods. Land Degradation and Development 21,303-309.

Boardman, J., Favis-Mortlock, D.T., 1993. Climate change and soil erosion in Britain. The Geographical Journal 159 (2), 179-183.

Brissette, F.P., Leconte, R., Minville, M., 2006. Can we adequately quantify the increase/decrease of flooding due to climate change. In: EIC Climate Change Technology Conference 2006, Ottawa, May 10-12.

Cochrane, T.A., Flanagan, D.C., 1999. Assessing water erosion in small watersheds using WEPP with GIS and digital elevation models. Journal of Soil and Water Conservation 54 (4), 678-685.

Crawford, T., 2007. Future Climate Change: Modelling the Implications of Shifts in Rainfall Characteristics for Runoff in Northern Ireland. Unpublished Ph.D. thesis, Queen's University Belfast.

Cruickshank, J.G., 1997. Soil and Environment: Northern Ireland. Department of Agriculture and Rural Development/Queen's University Belfast, Belfast.

Dobbins, C.L., Han, Y., Preckel, P., Doster, D.H., 1994. Purdue Crop/Livestock Linear Program: User's Manual. E-EC-6. Purdue University, West Lafayette, IN, USA

Evans, R., 1993. Extent frequency and rates of rilling of arable land in localities in England and Wales. In: Wicherek (Ed.), Farm Land Erosion: In Temperate Plains Environment and Hills. Elsevier, Michigan.

Evrard, O., Bielders, C.L., Vandaele, K., Van Wesemael, B., 2007. Spatial and temporal variation in muddy floods in central Belgium, off-site impacts and potential control measures. Catena 70, 443-454.

Favis-Mortlock, D.T., Boardman, J., 1995. Nonlinear responses of soil erosion to climate change: a modelling study on the UK South Downs. Catena 25, 365-387.

Favis-Mortlock, D.T., Guerra, A.J.T., 1999. The implications of general circulation model estimates of rainfall for future erosion: a case study from Brazil. Catena 37, 329-354.

Favis-Mortlock, D.T., Guerra, A.J.T., 2000. The influence of global greenhouse-gas emissions on future rates of soil erosion: a case study from Brazil using WEPP$\mathrm{CO}_{2}$. In: Schmidt, J. (Ed.), Soil Erosion: Application of Physically Based Models. Springer-Verlag, Berlin.
Favis-Mortlock, D.T., Savabi, M.R., 1996. Shifts in rates and spatial distributions of soil erosion and deposition under climate change. In: Anderson, M.G., Brooks, S.M. (Eds.), Advances in Hillslope Processes, vol. 1. Wiley, Chichester.

Fealy, R., Sweeney, J., 2008. Statistical downscaling of temperature, radiation and potential evapotranspiration to produce a multiple GCM ensemble mean for a selection of sites in Ireland. International Journal of Climatology 41 (1), $1-27$.

Feng, X., Wang, Y., Chen, L., Fu, B., Bai, G., 2010. Modelling soil erosion and its response to land-use change in hilly catchments of the Chinese Loess Plateau. Geomorphology 118, 239-248.

Flanagan, D.C., Livingston, S.J., 1995. USDA - Water Erosion Prediction Project (WEPP) User Summary. West Lafayette, Indiana.

Flanagan, D.C., Nearing, M.A., 1995. USDA - Water Erosion Prediction Project (WEPP) Hillslope Profile and Watershed Model Documentation. West Lafayette, Indiana.

Flato, G.M., Boer, G.J., Lee, W.G., McFarlane, N.A., Ramsden, D., Reader, M.C., Weaver A.J., 2000. The Canadian centre for climate modelling and analysis global coupled model and its climate. Climate Dynamics 16, 451-546.

Gordon, C., Cooper, C., Senior, A., Banks, H., Gregory, J.M., Johns, T.C., Mitchell, J.F.B. Wood, R.A., 2000. The simulation of SST, sea ice extents and ocean heat transports in a version of the Hadley Centre coupled model without flux adjustments. Climate Dynamics 16, 147-168, doi:10.1007/s003820050010.

Gordon, H.B., O'Farrell, S.P., 1997. Transient climate change in the CSIRO coupled model with dynamic sea ice. Monthly Weather Review 125, 875-907.

Hoogenboom, G., Wilkens, P.W., Thornton, P.K., Jones, J.W., Hunt, L.A., Imamura, D.T. 1999. Decision support system for agrotechnology transfer v3. 5. In: Hoogenboom, G., Wilkens, P.W., Tsuji, G.Y. (Eds.), DSSAT Version 3, 4. University of Hawaii, Honolulu, HI, USA, pp. 1-36.

IPCC, 2007. Climate Change 2007. (On-line) IPCC. http://www.ipcc.ch (accessed 17.10.08).

Kirkbride, M.P., Reeves, A.D., 1993. Soil erosion caused by low-intensity rainfall in Angus, Scotland. Applied Geography 13, 299-311.

Klik, A., Eitzinger, J., 2010. Impact of climate change on soil erosion and the efficiency of soil conservation practices in Austria. Journal of Agricultural Science 148, 529-541.

Lal, R. (Ed.), 1998. Soil Quality and Soil Erosion. CRC Press, Boca Raton, FL

Lambin, E.F., Turner, B.L., Geist, H.J., Agbola, S.B., Angelsen, A., Bruce, A.W., Coomes, O.T., Dirzo, R., Fischer, G., Folke, C., George, P.S., Homewood, K., Imbernon, J., Leemans, R., Li, K., Moran, E.F., Mortimore, M., Ramakrishnan, P.S., Richards, J.F., Skånes, H., Steffen, W., Stone, G.D., Svedin, U., Veldkamp, T.A., Vogel, C., Xu, J. 2001. The causes of land-use and land-cover change: moving beyond the myths. Global Environmental Change 11 (4), 261-269.

Nakicenovic, N., Swart, R. (Eds.), 2000. Special Report on Emissions Scenarios. A Special Report of Working Group III of the Intergovernmental Panel on Climate Change. Cambridge University Press, Cambridge, UK/New York.

Nearing, M.A., 2001. Potential changes in rainfall erosivity in the U.S with climate change during the 21st century. Journal of Soil and Water Conservation 56 (3), 229-232.

Nearing, M.A., Jetten, V., Baffaut, C., Cerdan, O., Couturier, A., Hernandez, M., Le Bissonnais, Y., Nichols, M.H., Nunes, J.P., Renschler, C.S., Souchère, V., van Oost, K., 2005. Modeling response of soil erosion and runoff to changes in precipitation and cover. Catena 61, 131-154.

Nicks, A.D., Lane, L.J., Gander, G.A., 1995. Weather generator. In: Flanagan, D.C., Nearing, M.A. (Eds.), Hillslope Profile and Watershed Model Documentation, NSERL Report No. 10, 2.1-2.2. West Lafayette, Indiana.

Nicks, A.D., Williams, R.D., Gander, G.A., 1994. Estimating the impacts of global change on erosion with stochastically generated climate data and erosion models. Variability in Stream Erosion and Sediment Transport. In: Proceedings of the Canberra Symposium, December.

O’Neal, M.R., Nearing, M.A., Vining, R.C., Southworth, J., Pfeifer, R.A., 2005. Climate change impacts on soil erosion in Midwest United States with changes in crop management. Catena 61, 165-184

Parry, M.L., 2002. Scenarios for climate impact and adaptation assessment. Global Environmental Change 12,149-153.

Pfeifer, R.A., Habeck, M., 2002. Farm level economic impacts of climate change. In: Doering, O.C., Randolph, J.C., Southworth, J., Pfeifer, R.A. (Eds.), Effects of Climate Change and Variability on Agricultural Production Systems. Kluwer Academic Publishers, Boston, Massachusetts.

Pimentel, D., 2006. Soil erosion: a food and environmental threat. Environment Development and Sustainability 8, 119-137.

Pruski, F.F., Nearing, M.A., 2002a. Climate-induced changes in erosion during the 21 st century for eight U.S. locations. Water Resources Research 38 (12), Article no. 1298.

Pruski, F.F., Nearing, M.A., 2002b. Runoff and soil loss responses to changes in precipitation: a computer simulation study. Journal of Soil and Water Conservation 57 (1), 7-16.

Richardson, C.W., 1981. Stochastic simulation of daily precipitation, temperature and solar radiation. Water Resources Research 17 (1), 182-190.

Robinson, D.A., Blackman, J.D., 1990. Some costs and consequences of soil erosion and flooding around Brighton and Hove, autumn 1987. In: Boardman, J., Foster, I.D.L., Dearing, J.A. (Eds.), Soil Erosion on Agricultural Land. Wiley, Chichester, pp. 369-382.

Rosenzweig, C., Hillel, D., 1998. Climate Change and the Global Harvest. Potential Impacts of the Greenhouse Effect on Agriculture. Oxford University Press Inc., New York.

Southworth, J., Habeck, M., Pfeifer, R.A., Randolph, J.C., Doering, O., Johnston, J., Gangadhar Rao, D., 2002. Changes in soybean yields in the Midwestern United States 
as a result of future changes in climate, climate variability and $\mathrm{CO}_{2}$ fertilisation. Climatic Change 53, 447-475.

Taddese, G., 2001. Land degradation: a challenge to Ethiopia. Environmental Management 27 (6), 815-824.

Toy, T.J., Foster, G.R., Renard, K.G., 2002. Soil Erosion: Processes, Prediction, Measurement and Control. Wiley, New York.

Trenberth, K.E., Dai, A., Rasmussen, R.M., Parsons, D.B., 2003. The changing character of precipitation. Bulletin of the American Meteorological Society 84 (9), 1205-1217.

UN, 2005. World Population Prospects: The 2004 Revision. United Nations, New York, ESA/P/WP.193.

Watson, A., Evans, R., 1991. A comparison of estimates of soil erosion made in the field and from photographs. Soil and Tillage Research 19, 17-27.

Watson, C.J., Foy, R.H., 2001. Environmental impacts of nitrogen and phosphorus cycling in grassland systems. Outlook Agriculture 30, 117-127.

Watson, C.J., Jordan, C., Lennox, S.D., Smith, R.V., Steen, R.W.J., 2000. Inorganic nitrogen in drainage water from grazed grassland in Northern Ireland. Journal of Environmental Quality 29, 225-232.

Wilby, R.L., Dawson, C.W., 2007. SDSM 4.2 - A Decision Support Tool for the Assessment of Regional Climate Change Impacts. SDSM User Manual. Lancaster University, UK.

Wilby, R.L., Wigley, T.M.L., 1997. Downscaling general circulation model output: a review of methods and limitations. Progress in Physical Geography 21, 53-548.

Wilcock, D.N., 1997. Rivers, drainage basins and soils. In: Cruickshank, J.G. (Ed.), Soil and Environment: Northern Ireland. Department of Agriculture and Rural Development/Queen's University Belfast, Belfast, pp. 85-98.
Williams, J., Nearing, M.A., Nicks, A., Skidmore, E., Valentine, C., King, K., Savabi, R. 1996. Using soil erosion models for global change studies. Journal of Soil and Water Conservation 51 (5), 381-385.

Yang, D., Kanae, S., Oki, T., Koike, T., Musiake, K., 2003. Global potential soil erosion with reference to land use and climate changes. Hydrological Processes 17, 2913-2928.

Yu, B., 2003. An assessment of uncalibrated CLIGEN in Australia. Agricultural Meteorology $119,131-148$.

Zhang, X.C., 2007. A comparison of explicit and implicit spatial downscaling of GCM output for soil erosion and crop production assessments. Climatic Change 84, 337-363.

Zhang, X.C., 2005. Spatial downscaling of global climate model output for sitespecific assessment of crop production and soil erosion. Agricultural and Forest Meteorology 135, 215-229.

Zhang, X.C., Liu, W.Z., 2005. Simulating potential response of hydrology, soil erosion, and crop productivity to climate change in Changwu tableland region on the Loess Plateau of China. Agricultural and Forest Meteorology 131, $127-142$.

Zhang, X.C., Liu, W.Z., Li, Z., Zheng, F.L., 2009. Simulating site-specific impacts of climate change on soil erosion and surface hydrology in southern Loess Plateau of China. Catena 79 (3), 237-242.

Zhang, X.C., Nearing, M.A., 2005. Impact of climate change on soil erosion, runoff and wheat productivity in central Oklahoma. Catena 61, 185-195.

Zhang, X.C., Nearing, M.A., Garbrecht, J.D., Steiner, J.L., 2004. Downscaling monthly forecasts to simulate impacts of climate change on soil erosion and wheat production. Soil Science Society of America Journal 68, 1376-1385. 